\title{
ANALISIS DAMPAK WAKTU TANAM TANAMAN TOMAT TERHADAP BIAYA PRODUKSI, HARGA DAN PENDAPATAN USAHA TANI TOMAT DI KECAMATAN ALAS KABUPATEN SUMBAWA
}

\author{
ANAL YSIS OF THE IMPACT OF TOMATO PLANTING TIME \\ ON COSTS, PRICES AND DATA COLLECTION OF TOMATO FARMING \\ IN ALAS DISTRICT, SUMBAWA REGENCY
}

\author{
Selfiyah Safitri ${ }^{1}$, Bambang Dipokusumo ${ }^{1}$, Syarif Husni ${ }^{1}$ \\ ${ }^{1}$ Progam Studi Agribisnis Universitas Mataram, Mataram, Indonesia \\ *Email Penulis korespondensi:selfiyah98@gmail.com
}

\begin{abstract}
ABSTRAK
Penelitian ini bertujuan untuk mengkaji perbedaan struktur biaya dan pendapatan usahatani tomat pada berbagai musim tanam di Kecamatan Alas Kabupaten Sumbawa. Data yang dikumpulkan adalah data primer melalui kuisioner dan data sekunder yaitu data yang diperoleh dari BPS serta karya tulis ilmiah yang berkaitan dengan penelitian ini. Teknis analisis nya adalah teknik survei dan disajikan dalam bentuk tabel. Hasil penelitian ini menunjukan bahwa rata-rata biaya yang dikelurkan usahatani tomat pada musim tanam pertama sebesar Rp Rp 75.047.412/Ha sedangkan biaya ushatani tomat yang dikeluarkan pada musim tanam kedua sebesar Rp 64.273.351/Ha, rata-rata harga tomat pada musim tanam pertama sebesar Rp 11.790 per kg sedangkan pada musim tanam kedua sebesar Rp 5.435 per kg dan pendapatan Pada musim tanam pertama pendapatan usahatani tomat sebsar Rp 150.430.781/Ha sedangkan untuk musim tanam kedua sebesar Rp 20.304.842/Ha. Hal ini menunjukan bahwa ada perbedaan yang signifikan biaya dan pendapatan usahatani tomat pada berbagai musim tanam di Kecamatan Alas Kabupaten Sumbawa.

Kata Kunci : Perbandingan Biaya Produksi, Harga dan Pendapatan Usahatani Tomat
\end{abstract}

\begin{abstract}
This study aims to examine the differences in the cost structure and income of tomato farming at various planting seasons in Alas Subdistrict, Sumbawa Regency. The data collected is primary data through questionnaires and secondary data, namely data obtained from BPS and scientific papers related to this research. The analysis technique is a survey technique and is presented in tabular form. The results of this study indicate that the average cost spent on tomato farming in the dry season is IDR 75.047.412/ ha, while the cost of tomato farming during the rainy season is IDR 64.273.351/ ha, the average price of tomatoes in the dry season is IDR Rp. 11,790 per $\mathrm{kg}$, while in the rainy season it is Rp. 5,435 per $\mathrm{kg}$ and income. In the dry season, income from tomato farming is $\mathrm{Rp} 150.430 .781$ / ha, while for the rainy season it is $\mathrm{Rp} 20.304 .842 /$ ha. This shows that there are significant differences in the costs and income of tomato farming in various planting seasons in Alas District, Sumbawa Regency.

Keywords: Comparison of Production Costs, Prices and Tomato Farming Income
\end{abstract}

\section{PENDAHULUAN}

Sektor pertanian masih merupakan leading sector yang memiliki peran penting dan strategis dalam perekonomian nasional (Nursan \& Septiadi, 2020). Peran startegis pertanian tersebut digambarkan melalui kontribusi yang nyata melalui pembentukan capital, penyediaan bahan pangan, bahan baku industri, pakan dan bio-energi, penyerapan tenaga kerja, sumber devisa negara, dan sumber pendapatan, serta pelastarian lingkungan melalui praktek usahatani yang ramah lingkungan (DPTPH Provinsi Nusa Tenggara Barat, 2015).

Hortikultura merupakan salah satu komoditas yang mempunyai potensi besar untuk dikembangkan. Ketersediaan berbagai jenis tanaman hortikultura, yang meliputi tanmaan buah-buahan, sayur-sayuran, tanaman hias dan obat-obatan yang dimiliki 
Indonesia dapat menjadi kegiatan usaha ekonomi yang sangat menguntungkan apabila dapat dikelola secara optimal (BPS Provinsi NTB, 2016).

Perkembangan komoditas hortikultura, terutama sayur-sayuran, baik sayuran daun maupun sayuran buah, cukup potensial dan prospektif karena didukung oleh potensi sumber daya alam, sumber daya manusia, ketersediaan teknologi, dan potensi serapan pasar dalam negeri maupun pasar internasional yang terus meningkat. Salah satu jenis tanaman sayuran buah yang banyak dikonsumsi oleh masyarakat adalah tomat. Tomat merupakan salah satu jenis tanaman sayuran buah yang dapat dibudidayakan secara komersial di daerah tropis. Pada umumnya tomat digunakan sebagai kebutuhan dapur, bahan industri, obat-obatan, dan lain sebagainya. Dengan demikian beragamnya penggunaan tomat, maka permintaan akan sayuran buah tomat di dalam negeri semakin meningkat dari waktu ke waktu. Sadar akan peningkatakan tersebut, maka semakin banyak petani yang membudidayakannya. NTB merupakan salah satu daerah yang potensial untuk mengembangkan tanaman tomat (BPS NTB, 2017).

Dalam menjalankan usahatani tomat tentu saja tidak selalu berjalan baik seperti yang diharapkan oleh petani, terdapat beberapa faktor yang mempengaruhi harga sehingga menjadi tidak stabil. Kenaikan harga tomat sangat tergantung pada sistem produksi atau musim panen dan waktu tanam tanaman tomat di Kecamatan Alas serta pengaruh iklim dan cuaca. Di samping itu, kenaikan harga juga berkaitan dengan kegiatan pemasaran. Biasanya turunya harga tomat terjadi pada musim panen raya, ketika para petani secara bersamaan menjual hasil panennya. Jumlah tomat beredar dipasaran akan lebih banyak dari pada permintaan. Akibatnya, harga pun turun. Hal ini akan berdampak pada pendapatan petani dan keluarganya. Berdarkan uraian tersebut, maka perlu melakukan penelitian tentang "Analisis Dampak Waktu Tanam Tanaman Tomat Terhadap Biaya Produksi, Harga, dan Pendapatan Usaha Tani di Kecamtaan Alas Kabupaten Sumbawa".

\section{METODE PENELITIAN}

Metode yang digunakan dalam penelitian ini adalah metode deskriptif, yaitu metode yang dibertujuan untuk memecahkan masalah dan memberikan gambaran secara akurat mengenai objek penelitian yang ada pada waktu sekarang dengan cara mengumpulkan data, menyusun, menganalisis dan menjelaskan data untuk mencapai kesimpulan. Teknik pengumpulan data data dalam penelitian ini adalah teknik survei yaitu data dikumpulkan dari sejumlah individu (unit sampling) dalam waktu yang bersamaan dengan menggunakan daftar pertanyaan yang telah di susun sebelumnya (Sugiyono, 2014).

Penelitian ini dilakukan di Kecamatan Alas Kabupten Sumbawa tahun 2020. Kecamatan Alas ini terdiri dari tujuh desa, ditetapkan dua desa sebagai sempel yaitu Desa Juranalas dan Desa Labuhan alas secara "purpposive sampling" atas pertimbangan desa tersebut memiliki jumlah petani tomat terbanyak dan melakukan usahatani tomat pada dua musim tanam.

Unit analisis adalah petani yang melakukan usahatani tomat di Kecamatan Alas Kabupaten Sumbawa. Penentuan jumlah responden dilakukan dengan teknik non probability sampling yaitu dengan sampling jenuh (sensus) yaitu metode penarikan sampel bila semua anggota populasi dijadikan sebagai sampel. Hal ini sering dilakukan apabila jumlah populasi kecil, kurang dari 30 orang. 


\section{Analisis Data}

\section{Analisis Biaya dan Pendapatan dalam Usahatani}

Untuk tujuan pertama, kedua dan ketiga formulasi analisis yang digunakan Persamaan keuntungan yaitu sebagai berikut: (Sugiyono, 2014; Suratiyah, 2015; Nursan, Ayu, \& Suparyana, 2020);

- $\quad$ Biaya (TC)

$\mathrm{TC}=\mathrm{TFC}-\mathrm{TVC}$

Keterangan :

$\mathrm{TC}=$ Total cost (Biaya Total dari usahatani tomat, biaya tetap dan biaya variabel)

$\mathrm{TFC}=$ Total Fixed Cost (Total Biaya Tetap)

$\mathrm{TVC}=$ Total Variabel Cost (Total Biaya Variabel)

- Penerimaan (Total Revenue)

$\mathrm{TR}=\mathrm{P} \times \mathrm{Q}$

Keterangan :

$\mathrm{TR}=$ Total Reneue (Penerimaan atau total nilai penjualan)

$\mathrm{P}=$ Harga

$\mathrm{Q}=$ Jumlah Produksi

- Pendapatan (Income)

$\mathrm{I}=\mathrm{TR}-\mathrm{TC}$

Keterangan :

$\mathrm{I}=$ Income (Pendaptan)

$\mathrm{TR}=$ Total Revenue $($ Total Penerimaan $)$

$\mathrm{TC}=$ Total Cost (Biaya Total)

\section{Analisis Komparasi Biaya, Harga dan Pendapatan}

Untuk mengetahui perbedaan biaya, harga dan pendapatan usahatani tomat pada musim tanam pertama (September 2019 - Desember 2020) dengan usahatani tomat pada musim tanam kedua (Februari 2020 - April 2020) dapat dilakukan dengan analisis statistik uji beda rata-rata menggunakan t-hiitung dan uji homogenitas dengan uji $\mathrm{F}$ pada taraf nyata $5 \%$.

1.) untuk mengetahui homogenitas tidaknya varians kedua sampel digunakan uji $F$ hitung pada taraf nyata 5\% dengan rumus sebagai berikut (Sudjana, 1992) :

$\mathrm{F}$ hit $=\frac{S X_{1}^{2}}{S X_{2}^{2}}$, jika $S X_{1}^{2}>S X_{2}^{2}$

Jika $\mathrm{F}$ hitung $<\mathrm{F}$ tabel : berarti varians kedua sempel homogen.

Jika $\mathrm{F}$ hitung $>\mathrm{F}$ tabel : berarti varians kedua sempel tidak homogen

$S X_{1}^{2} \sum \frac{\left(X_{1}-X_{1}\right)^{2}}{n-1}$ atau $S X_{1}^{2}=\frac{1}{n-1} \sum X_{1}^{2}-\left(\sum X_{1}\right)^{2} / n$

2.) untuk mengetahui analisis untuk uji beda rata-rata menggunakan t-hiutng dengan taraf nyata 5\% dengan rumus hipotesis sebagai berikut :

Uji Hipotesis :

Ho : $\mu_{1}=\mu_{2}$ (Tidak ada perbedaan rata-rata biaya, harga atau pendapatan usahatani tomat pada musim tanam pertama dan musim tanam kedua di Kecamatan Alas Kabupaten Sumbawa).

$\mathrm{HI}: \mu_{1} \neq \mu_{2}$ (Ada perbedaan rata-rata biaya, harga dan pendapatan usahatani tomat pada musim tanam pertama dan musim tanam kedua di Kecamatan Alas Kabupaten Sumbawa).

Dimana :

$\mu_{1}=$ Rata - rata variabel 1 (Usahatani tomat pada musim tanam pertama)

$\mu_{2}=$ Rata - rata variabel 2 (Usahatani tomat pada musim tanam kedua) 
Rumus Persamaan :

a.) Apabila varians kedua sempel homogen, maka menggunakan rumus :

$$
\begin{aligned}
\mathrm{t} \text { hit } & =\frac{\bar{X}_{1}-\bar{X}_{2}}{\sqrt{\frac{S P^{2}}{n_{1}}+\frac{S P^{2}}{n_{2}}}} \\
S P^{2} & =\frac{\left(n_{1}-1\right) S X_{1}^{2}+\left(n_{2}-1\right) S X_{2}^{2}}{\left(n_{1}-1\right)+\left(n_{2}-1\right)}
\end{aligned}
$$

b.) Apabila varians kedua sempel tidak homogen, maka menggunakan rumus :

$$
\mathrm{thit}=\frac{\bar{X}_{1}-\bar{X}_{2}}{\sqrt{\frac{s X_{1}^{2}}{n_{1}}+\frac{s X_{2}^{2}}{n_{2}}}}
$$

Kriteria Keutusan :

Jika $\mid \mathrm{t}$ - hitung $\mid \geq \mathrm{t}$-tabel maka, Ho ditolak.

Jika $\mid \mathrm{t}$ - hitung $\mid \leq \mathrm{t}$-tabel maka, Ho diterima.

Keterangan :

$X_{1}=$ Rata-rrata biaya, harga dan pendapatan usahtani tomat pada musim tanam pertama

$X_{2}=$ Rata-rata biaya, harga dan pendapatan usahatani tomat pada musim tanam kedua

$S P^{2}=$ Varian gabungan

$S X_{1}=$ Varian usahatani tomat pada musim tanam pertama

$S X_{2}=$ Varian usahatani tomat pada musim tanam kedua

$n_{1}=$ jumlah responden usahatani tomat pada musim tanam pertama

$n_{2}=$ jumlah responden usahatani tomat pada musim tanam kedua

\section{Analisis Kendala Usahatani}

Untuk mengetahui masalah atau kendala-kendala yang dihadapi oleh petani dalam usahatani tomat pada berbagai musim tanam di Kecamatan Alas Kabupaten Sumbawa, dilakukan dengan menginventarisir dan mengidentifikasi, kemudian dengan mentabulasi dan mendeskripsikan kendala baik masalah tekniks dan masalah ekonomi.

\section{HASIL DAN PEMBAHASAN}

\section{Karakteristik Responden}

Kisaran umur petani reponden tomat di Kecamatan Alas Kabupaten Sumbawa semuanya berada dikisaran usia 25-64 tahun sebanyak 17 orang (100\%). Hal ini menunjukan bahwa umur responden pada usahatani tomat termasuk dalam kategori usia produktif yang artinnya kemampuan mental, sikap, dan keterampilan serta fisik mampu melakukan kegiatan usahatani. Untuk tingkat pendidikan petani tomat di Kecamatan Alas Kabupaten Sumbawa didominasi oleh Sekolah Menengah Atas (SMA) 9 orang (53\%) dan Sekolah Dasar (SD) 5 orang (29\%), kemudian Sekolah Menengah Pertama (SMP) 3 orang $(18 \%)$. Hasil ppenelitian ini menunjukan bahwa pendidikan petani responden umunya telah menempuh pendidikan formal berarti petani sudah mempunyai bekal kemampuan membaca dan menulis. Kondisi ini tidak terlalu mempengaruhi tingkat pendapatan petani responden dikarenakan pekerjaan sebagai petani tidak memerlukan tingkat pendidikan yang tinggi tetapi memerlukan kekusatan fisik, pengalaman berusahatani maupun pengetahuan kondisi yang terjadi.

Pengalaman berusahatani secara umum terbanyak pada kisaran 3-10 tahun sebanyak 15 orang (88\%) sementara yang paling sedikit pada kisaran 11-20 tahun sebanyak 2 orang (12\%). Hal menunjukan bahwa responden cukup berpengalaman 
dalam ushatani tomat. Pengalaman ini merupakan modal dasar dalam menerima inovasi untuk meningkatkan pengalam produktivitas tenaga kerja. Sebagain besar petani responden tomat memiliki luas lahan yang berkisar $<0,50$ Ha sebanyak 16 orang (94\%), sedangkan yang memiliki luas lahan $0,50-1$ Ha sebanyak 1 orang $(6 \%)$. Secara ratarata luas lahan untuk berusahatani tomat pada berbagai musim tanam di Kecamatan Alas Kabupaten Sumbawa adalah 0,18 Ha. Dengan demikian mayaoritas petani responden tergolong dalam pengguna lahan semppit. Menurut Hermamnto (1989) dalam Ratna Sari (2018), kriteria penguasaan lahan dapat digolongkan menjadi lahan sempit $(<0,50 \mathrm{Ha})$, lahan sedang $0,50-1,00 \mathrm{Ha})$ dan lahan luas $(>1,00 \mathrm{Ha})$.

\section{Biaya Produksi}

Biaya produksi merupakan jumlah keseluruhan dari semua biaya variabel dan biaya tetap. Biaya variabel adalah biaya yang besar kecilnya tergantung dari besar kecilnya jumlah produksi yang meliputi biaya sarana produksi, penggunaan tenaga kerja, dan biaya variabel lain serta semua biaya diperhitungkan dalam satu kali proses produksi. Sedangkan biaya tetap adalah biaya yang besar kecilnya tidak dipengaruh oleh besar kecilnya produksi dan tidak habis dipakai dalam satu kali produksi yang meliputi biaya penyusutan alat, pajak tanah dan sewa lahan. Adapun rincian biaya produksi yang dikeluarkan petani selama usahatani tomat disajikan pad atabel 1 berikut :

Tabel 1. Rata-rata Total Biaya Produksi Per Hektar Pada Usahatani Tomat Pada Berbagai Musim Tanam di Kecamatan Alas Kabupaten Sumbawa pada tahun 2020.

\begin{tabular}{lrrrr}
\hline \multirow{2}{*}{$\begin{array}{c}\text { Jenis dan Komponen } \\
\text { Biaya }\end{array}$} & \multicolumn{2}{c}{ MT I } & \multicolumn{2}{c}{ MT II } \\
\cline { 2 - 5 } & Jumlah & $\begin{array}{c}\text { Persentase } \\
(\%)\end{array}$ & Jumlah & $\begin{array}{r}\text { Persentase } \\
\text { (\%) }\end{array}$ \\
\hline Biaya Variabel & 69.138 .845 & 92.12 & 59.605 .270 & 92.73 \\
\hline a. Baiya Saprodi & 29.179 .344 & 42.20 & 31.275 .052 & 52.48 \\
b. Biaya Tenaga Kerja & 39.959 .502 & 57.79 & 28.330 .218 & 47.52 \\
\hline Biaya Tetap & 5.908 .566 & 7,88 & 4.668 .081 & 7,27 \\
\hline a. Biaya Penyusutan & 2.247 .001 & 38.02 & 1.226 .531 & 26.28 \\
Alat & 119.938 & 2.02 & 119.938 & 2.57 \\
b. Pajak Lahan & 1.910 .592 & 32.33 & 1.910 .592 & 40.92 \\
c. Sewa Lahan & 1.631 .036 & 27.60 & 1.411 .020 & 30.22 \\
d. Lain-lain & 75.047 .412 & 100 & 64.273 .351 & 100 \\
\hline Biaya Total & & & &
\end{tabular}

Sumber : Data primer diolah, 2021

Baiya variabel merupakan biaya yang dikeluarkan yang habis terpakai dalam satu kali proses produksi dan mempengaruhi besar kecilnya jumlah produksi. Biaya variabel dalam penelitian ini meliputi biaya sarana dan sarana produksi (seperti: bibit, pupuk, pestisida) dan tenaga kerja.

Pada tabel 1. menunjukan bahwa rata-rata biaya sarana produksi usahatani tomat pada musim tanam kedua yaitu sebesar Rp 31.275.052 per hektar lebih besar dibandingkan rata-rata biaya biaya variabel musim tanam pertama yaitu sebesar $\mathrm{Rp}$ 29.179.344 per hektar. Perbedaaan biaya produksi pada musim tanam pertama dan musim kedua disebabkan oleh curah hujan yang cukup tinggi pada musim tanam kedua, 
hal ini menyebabkan banyak bibit yang gagal tumbuh dan tanaman lebih banyak diserang penyakit pada musim tanam kedua dibandingkan dengan musim tanam kedua. Sehingga pada musim tanam kedua petani sedikit mengeluarkan biaya ekstra pada biaya sarana produksi khusus nya pada biaya pembelian bibit untuk mengantisipasi banyak bibit yang gagal tumbuh akibat curah hujan yang tinggi dan biaya pembelian pestisida untuk menanggulagi atau mengatasi rengan penyakit dan hama.

Kemudian tenaga kerja adalah salah satu unsur penentu dan merupakan faktor produksi yang mempunyai peranan penting dalam proses produksi. Banyak sedikitnya tenaga kerja yang diperlukan tergantung dari jenis komoditi yang diusahakan, tingkat teknologi yang digunakan, sifat usahatani nya, topografi, dan tanah (Surantiah, 2008), sehingga akan berpengaruh terhadap besar biaya yang harus dikeluarkan petani. Dalam penelitian ini diperhitungkan jumlah tenaga kerja baik dalam maupun luar keluarga.

Berdasarkan tabel 1 jumlah nilai atau total upah yang dikeluarkan petani pada Musim tanam pertama sebesar Rp 39.959.502, sedangkan pada Musim tanam kedua total upah sebesar Rp 28.330.218. Perbedaan biaya terjadi dikarenakan pada saat Musim tanam kedua petani masih menggunakan lahan yang sama ketika melakukan usahatani tomat pada musim pertama, sehingga pada Musim tanam kedua pertani tidak lagi mengeluarkan biaya tenaga kerja untuk pengelolahan lahan, pemasangan bedengan dan pemasangan ajir. Sehingga membuat biaya tenaga kerja pada Musim tanam kedua menjadi berkurang atau lebih sedikit.

Penyusutan alat merupakan nilai yang terdapat pada suatu alat dengan melihat nilai beli dari barang tersebut, nilai sisah dan umur ekonomis barang tersebut, pada tabel 1 di atas dapat dilihat bahwa rata-rata biaya penyusutan alat petani responden pada usahatani tomat pada Musim tanam pertama sebesar Rp 2.247.001 per hektar sedangkan pada usahatani Musim tanam kedua sebesar Rp 1.226.531 per hektar. Biaya penyusutan tertinggi pada usahtani tomat yaitu pada biaya penyusutan mulsa sebesar Rp 926.791 per hektar pada Musim tanam pertama dan Rp 456.646 per hektar pada Musim tanam kedua, biaya penyusutan mulsa pada Musim tanam kedua lebih rendah daripada Musim tanam pertama dikarenakan mulsa yang digunakan pada Musim tanam pertama digunakan kembali pada Musim tanam kedua sehingga membuat harga beli dan harga jual mulsa pada Musim tanam kedua berkurang sehingga membuat biaya penyusutan nya menjadi lebih rendah dibandingkan pada Musim tanam kedua. Begitu juga dengan perbedaan biaya penyusutan terai semai, biaya penyusutan terai semai pada Musim tanam kedua lebih tinggi dibandingkan Musim tanam pertama, hal ini dikarenakan banyak nya bibit yang akan ditanam pada Musim tanam kedua sehingga membuat petani harus membeli jumlah terai semai lebih banyak pada Musim tanam kedua sehingga membuat biaya penyusutan terai semai menjadi lebih besar pada Musim tanam kedua. Perbedaan biaya penyusutan ini juga terjadi pada biaya penyusutan ajir dan tali ajir dimana pada Musim tanam pertama biaya penyusutan ajir sebesar Rp 899.169 per hektar sedangkan pada Musim tanam pertama sebesar Rp 385.358 per hektar, dan untuk biaya penyusutan tali ajir pada musim tanam pertama sebesar Rp 90.083 rupiah per hektar sedangkan pada musim tanam kedua biaya penyusutan untuk tali ajir sebesar Rp 43.030 rupiah per hektar, perbedaan biaya ini juga dikarenakan ajir dan tali ajir yang sudah digunakan pada budidaya Musim tanam pertama kembali digunakan lagi pada budidaya Musim tanam kedua sehingga harga jual dan biaya penyusutan dari ajir tersebut menjadi berkurang. Dan biaya penyusutan terendah pada usahatani tomat adalah pada Ember dengan nilai rata-rata sebesar Rp 11.137 per hektar. Jumlah tinggi rendahnya biaya penyusutan ditentukan olah jumlah alat yang digunakan, harga alat, nilai sisa dan umur ekonomis. 
Selain Penyusutan alat, biaya tetap yang diperhitungkan dalam penelitian ini adalah pajak lahan. Rata-rata pajak lahan petani responden pada usahatani tomat sebesar Rp 119.938 per hektar. Adapaun sewa lahan yang diperhitungkan dalam penelitian ini memiliki rata-rata sebesar Rp 1.910 .592 per hektar. Pada tabel 1 juga terdapat biaya lain-lain yang dimana pada Musim tanam pertama jumlah biaya lain-lain sebesar Rp 1.631.036 per hektar sedangkan biaya lain-lain pada Musim tanam kedua sebesar Rp 1.411.020 per hektar. Jumlah biaya lain-lain pada Musim tanam kedua lebih sedikit dibandingkan dengan total biaya lain-lain pada Musim tanam pertama, biaya pembelian plastik semai dan kokopit yang akan di jadikan sebagai media tanam bibit pada musim tanam kedua lebih besar dibandingkan musim tanam pertama hal ini diakibatkan penambahan jumlah bibit yang di tanam pada Musim tanam kedua akibat curah hujan yang tinggi yang mengakibatkan banyak bibit yang gagal tumbuh, dan faktor produksi yang menurun pada Musim tanam kedua mengakibatkan biaya pembelian keranjang pada Musim tanam kedua juga ikut berkurang, hal itulah yang membuat biaya lain-lain yang dikeluarkan petani pada Musim tanam kedua lebih sedikit dibandingkan biaya lain-lain yang dikeluarkan pada Musim tanam pertama.

\section{Produksi, Nilai dan Pendapatan Usahatanu Tomat}

Produksi adalah jumlah produksi tomat yang diperolah petani selama dua kali musim tanam. Nilai produksi (penerimaan) adalah hasil kali antara jumlah produksi tomat $(\mathrm{Kg})$ dengan harga produksi yang berlaku per kilogram $(\mathrm{Rp} / \mathrm{Kg})$. Keuntungan dari usahatani tomat diperoleh dengan menghitung total penerimaan dikurangi biaya produksi yang dikeluarkan oleh petani selama proses produksi. Untuk lebih rinci dapat dilihat pda tabel 2 berikut :

Tabel 2. Rata-rata Produksi, Nilai Penerimaan, Biaya Produksi, Pendapatan, dan RC Ratio Per Hektar Usahatani Tomat Pada Berbagai Musim Tanam di Kecamatan Alas Kabupaten Sumbawa Tahun 2020.

\begin{tabular}{llrr}
\hline \multirow{2}{*}{ No } & \multicolumn{1}{c}{ Uraian } & \multicolumn{2}{c}{ MT I } \\
(September - Desember 2020) & $\begin{array}{c}\text { MT II } \\
\text { (Februari 2020 - April } \\
\text { 2020) }\end{array}$ \\
\hline 1 & Produksi (Kg) & 15.424 & 12.178 \\
2 & Harga (Rp/Kg) & 11.790 & 5.435 \\
3 & Nilai Penerimaan (Rp) & 225.478 .193 & 84.578 .193 \\
4 & Biaya Produksi (Rp) & 75.047 .412 & 64.273 .351 \\
5 & Pendapatan (Rp) & 150.430 .781 & 20.304 .842 \\
6 & RC Ratio (Rp) & 2,98 & 1,28 \\
\hline
\end{tabular}

Sumber : Data Primer Diolah, 2020

Pada tabel 2 menjelaskan bahwa rata-rata jumlah produksi tomat yang dihasilkan petani pada Musim tanam pertama adalah sebesar $15.424 \mathrm{Kg}$ per hektar sedangkan pada Musim tanam kedua sebesar $12.178 \mathrm{~kg}$ per hektar. Jumlah produksi tomat pada Musim tanam pertama lebih besar dibandingkan dengan jumlah produksi tomat pada Musim tanam kedua, hal ini dikarenakan pada Musim tanam kedua curah hujan cukup besar sehingga banyak menggugurkan bunga sehingga jumlah tomat yang dapat berbuah sedikit berkurang dibandingkan pada Musim tanam pertama, dan ditambah lagi resiko diserang hama dan penyakit pada Musim tanam kedua membuat banyak tomat yang rusak dan busuk sehingga gagal panen.

Nilai penerimaan rata-rata yang diperolah petani tomat pada Musim tanam pertama sebesar Rp 225.478.193 per hektar dengan harga rata-rata per kg sebesar Rp $11.790 / \mathrm{kg}$, sedangkan pada Musim tanam kedua penerimaan yang diperolah petani sebesar Rp 84.578.193 per hektar dengan harga rata-rata per kg sebesar Rp 5.435/kg. 
Harga tomat pada Musim tanam pertama jauh lebih tinggi dibandingkan dengan Musim tanam kedua. Besarnya nilai penerimaan tergantung pada besarnya jumlah produksi dan harga jual tomat per kilogram. Semakin banyak produksi yang dihasilkan yang diikuti dengan tingginya harga jual produk, maka nilai penerimaan akan semakin besar, sebaliknya semakin sedikit jumlah produksi yang dihasilkan dan rendahnya harga jual maka nilai produksi semakin rendah. dengan demikian besar kecilnya nilai produksi akan mempengaruhi terhadap keuntungan yanng diterima petani.

RC Ratio rata-rata yang diperolah petani responden pada Musim tanam pertama sebesar 3 per hektar, yang artinya setiap satu rupiah biaya yang dikeluarkan akan menghasilkan 2,98 rupiah per hektar, sedangkan pada Musim tanam kedua sebesar 1,28 per hektar yang artinya setiap satu rupiah biaya yang dikeluarkan akan mengahsilkan 1,28 rupiah per hektar. Pendapatan rata-rata yang diperolah petani responden pada Musim tanam pertama sebesar Rp 149.908.300 per hektar selama satu kali produksi, sedangkan pendapatan pada Musim tanam kedua sebesar Rp 19.002.077 per hektar. Tinggi rendahnya keuntungan tomat dipengaruhi oleh besarnya biaya produksi yang dikorbankan dan nilai penerimaan yang diperolah, disamping itu juga faktor harga saat penjualan juga mempengeruhi keuntungan usahtani tomat. Dari hasil penelitian harga tomat pada Musim tanam pertama lebih tinggi dibandingkan pada Musim tanam pertama karena tidak ada nya pasokan tomat dari Lombok yang masuk ke Kecamatan Alas Kabupaten Sumbawa, sehingga pada Musim tanam pertama harga tomat menjadi lebih tinggi.

\section{Analisis Perbandingan Biaya dan Pendapatan Usahatani Tomat Pada Musim tanam pertama dan Musim tanam kedua}

Setelah dilakukan perbandingan analisis secara tabulasi, analisis dilanjutkan dengan menguji hipotesis yang diajukan dalam penelitian ini adalah biaya dan pendapatan usahtani tomat pada musim tanam pertama (Oktober 2019 - Januari 2020) dan musim tanam kedua (Februari 2020 - Mei 2020) di Kecamatan Alas Kabupaten Sumbawa. Untuk mengetahui bahwa masing-masing komponen biaya dan pendapatan usahatani tomat pada musim tanam dan musim tanam kedua memiliki perbedaan maka dilakukan uji lanjut yaitu uji F-test untuk menentukan apakah kedua variabel masingmasing usahatani tomat pada musim tanam pertama dan musim tanam kedua tersebut non signifikan (homogen) dan signifikan ( non homogen). Setelah dilakukan uji F-test pada masing-masing variabel maka didapatkan hasil pada tabel sebagai berikut :

Tabel. 3. Hasil uji F Biaya, Harga dan Pendapatan Usahatani Tomat Pada Musim tanam pertama dan Musim Tanam di Kecamatan Alas Kabupaten Sumbawa Tahun 2020.

\begin{tabular}{lrrrrl}
\hline Uraian & $\begin{array}{c}\text { MT I } \\
\text { (September - } \\
\text { Desember 2020) }\end{array}$ & $\begin{array}{c}\text { MT II } \\
\text { (Februari 2020 } \\
\text { April 2020) }\end{array}$ & F-hitung & F-tabel & Ket \\
\hline Biaya & 75.047 .412 & 64.273 .351 & 2,18 & 2,33 & Homogen \\
Pendapatan & 150.430 .781 & 20.304 .842 & 8,80 & 2,33 & $\begin{array}{l}\text { Tidak } \\
\text { homogen }\end{array}$ \\
Harga & 11.790 & 5.435 & 3,69 & 2,33 & $\begin{array}{l}\text { Tidak } \\
\text { homogen }\end{array}$ \\
\hline
\end{tabular}

Sumber : Data Primer Diolah, Tahun 2020

Setelah dilakukan uji $\mathrm{F}$ terhadap masing-masing biaya, harga dan pendapatan dapat dilihat bahwa untuk biaya nilai F-hitung $(2,18)<$ F-tabel $(2,33)$ yang menunjukan bawah varian kedua sempel homogen, untuk harga nilai F-hitung $(3,69)>$ F-tabel $(2,33)$ 
yang menunjukan bahwa varian kedua sempel tidak homogen, sedangkan untuk pendapatan nilai F-hitung $(8,80)>$ F-tabel $(2,33)$ yang menunjukan bahwa varian kedua sempel tidak homogen. Yang artinya perbedaan pendapatan lebih ditentukan oleh perbedaan harga, bukan dari perbedaan biaya usahatani tomat baik pada musim tanam pertama dan musim tanam kedua.

Setelah dilakukan uji F-test pada kedua variabel tersebut, maka dilakukan uji ttest untuk mengetahui perbandingan biaya, harga dan pendapatan pada usahatani tomat pada Musim tanam pertama dan Musim tanam kedua. Adapun hasil uji t-test dapat dilihat pada tabel 4

Tabel. 4. Hasil uji t Biaya dan Pendapatan Usahatani Tomat Pada Musim tanam pertama dan Musim Tanam di Kecamatan Alas Kabupaten Sumbawa Tahun 2020.

\begin{tabular}{lcrrrr}
\hline \multicolumn{1}{c}{ Uraian } & $\begin{array}{c}\text { MT I } \\
\text { (September - Desember } \\
\text { 2020) }\end{array}$ & $\begin{array}{c}\text { MT II } \\
\text { (Februari 2020 } \\
\text { April 2020) }\end{array}$ & t-hitung & t-tabel & Ket \\
\hline Biaya & 75.047 .412 & 64.273 .351 & 2,36 & 2,03 & Sig \\
Pendapatan & 150.430 .781 & 20.304 .842 & 4,32 & 2,08 & Sig \\
Harga & 11.790 & 5.435 & 23,58 & 2,06 & Sig \\
\hline
\end{tabular}

Sumber : Data Primer Diolah, Tahun 2020

Berdasarkan tabel 4 dapat dilihat uji t-test pada biaya, harga dan pendapatan usahatani tomat pada Musim tanam pertama dengan Musim tanam kedua menunjukan bahwa nilai t-hitung $>$ nilai t-tabel, maka Ho ditolak dan Ha diterima, artinya rata-rata biaya, harga dan pendapatan usahatani tomat pada Musim tanam pertama berbeda nayata atau signifikan dengan rata-rata biaya, harga dan pendapatan usahatani tomat pada Musim tanam kedua. Secara statistika, bahwa terdapat perbedaan yang nyata antara rata-rata biaya, harga dan pendapatan usahatani tomat pada Musim tanam pertama (September 2019 - Desember 2019) dengan rata-rata biaya, harga dan pendapatan usahatani tomat pada Musim tanam kedua (Februari 2020 - April 2020) di Kecamatan Alas Kabuapaten Sumbawa tahun 2020. Yang dimana hasil penelitian menunjukan bahwa biaya usahatani tomat pada Musim tanam pertama (Rp 75.047.412/Ha) lebih besar dibandingkan dengan biaya usahatani pada Musim tanam kedua (Rp 64.273.351/Ha), rata-rata harga tomat pada Musim tanam pertama ( $\mathrm{pp}$ $11.790 / \mathrm{kg}$ ) lebih besar dibandingkan rata-rata harga tomat pada Musim tanam kedua (Rp 5.435/kg) sedangkan untuk pendapatan usahatanu tomat pada Musim tanam pertama sebesar (Rp 150.430.781/Ha) juga lebih besar dibandingkan dengan pendapatan usahatani tomat pada Musim tanam kedua sebesar (Rp 20.304.842/Ha).

\section{Masalah dan Kendala-Kendala}

Dalam pelaksanaan usahatani tomat pada berbagai musim tanam di Kecamatan Alas Kabupaten Sumbawa,terdapat beberapa masalah atau kendala yang dihadapi petani, jumlah petani responden berdasarkan kendala-kendala dimaksud lebih jelas disajikan pada tabel 5 . 
Tabel 5. Jumlah Petani Responden Berdasarkan Kendala Yang Dihadapi Pada Usahatani Tomat Pada Berbagai Musim Tanam di Kecamatan Alas Kabupaten Sumbawa Tahun 2020

\begin{tabular}{llcccc}
\hline \multirow{2}{*}{ No } & \multirow{2}{*}{$\begin{array}{c}\text { Masalah Yang } \\
\text { dihadapi }\end{array}$} & $\begin{array}{c}\text { Jumlah } \\
\text { (Orang) }\end{array}$ & $\begin{array}{c}\text { Persentasi } \\
(\%)\end{array}$ & $\begin{array}{c}\text { Jumlah } \\
\text { (Orang) }\end{array}$ & $\begin{array}{c}\text { Persentasi } \\
(\%)\end{array}$ \\
\cline { 3 - 6 } & & - & - & 17 & 100 \\
\hline A, B, C & A, C & 17 & 100 & - & - \\
3 & D & - & - & 17 & 100 \\
4 & E & 17 & 100 & - & - \\
\hline
\end{tabular}

Sumber : Data Primer Diolah Tahun 2020

Keterangan :

$$
\begin{aligned}
& \text { A }=\text { Hama dan Penyakit } \\
& B=\text { Pemasaran (Harga Yang Rendah) } \\
& \text { C }=\text { Fluktuasi Harga (Harga Yang Tidak Menentu) } \\
& \text { D = Iklim dan Cuaca (Curah Hujan Yang Deras) } \\
& \text { E }=\text { Iklim dan Cuaca (Curah Hujan Yang Rendah) }
\end{aligned}
$$

Tabel 5 menunjukan bahwa faktor kendala yang dihadapi oleh petani pada usahatani tomat tidak hanya terdiri dari suatu faktor kendala. Masalah atau kendala usahatani tomat di Kecamatan Alas Kabupaten Sumbawa yaitu (A, B, C, = hama dan penyakkit, pemasaran/harga yang rendah, dan fluktuasi harga/haga yang tidak menentu) sebanyak 17 responden atau 100\% pada Musim tanam kedua. Hama dan penyakit yang dimaksud adalah organisme yang menggangu tanaman tomat sehingga pertumbuhan dan perkembangan tanaman tomat terhambat. Kendala $(\mathrm{A}, \mathrm{C}=$ Hama dan penyakit, fluktuasi harga/harga yang tidak menentu) sebanyak 17 responden atau $100 \%$ pada Musim tanam pertama. Fluktuasi harga yang dimaksud dalam penelitian ini adalah harga yang berubah-rubah, saat mulai penanaman harga tomat tinggi dan saat panen harga menjadi rendah. Kendala ( $\mathrm{D}=$ Iklim dan cuaca/curah hujan yang deras) sebanyak 17 respon atau $100 \%$ baik pada pada Musim tanam kedua. Curah hujan deras yang dimaksud di sini adalah banyak nya jumlah air yang jatuh di permukaan tanah datar selama periode tertentu, sehingga membuuat banyak bibit yang gagal tumbuh. Dan kendala ( $\mathrm{E}=\mathrm{Iklim}$ dan cuaca/curah hujan yang rendah) sebanyak 17 responden atau $100 \%$ pada Musim tanam pertama. Curah hujan rendah yang dimaksud di sini adalah sedikitnya jumlah air yang jatuh dipermukaan tanah datar selama periode tertentu, sehingga membuat beberapa petani yang lahan nya kering kesulitan mendaatkan air, sehingga mereka harus membuat sumur dan menyedot air dari sumur untuk menyiram atau mengairi tanaman tomat untuk beberapa waktu tertantu.

\section{KESIMPULAN DAN SARAN}

\section{Kesimpulan} berikut :

Berdasarkan hasil penelitian maka dapat disimpulkan beberapa hal sebagai

1. Terdapat perbedaan yang signifikan antara rata-rata biaya usahatani tomat pada Musim tanam pertama dan Musim tanam kedua, biaya produksi pada Musim tanam pertama lebih besar dibandingkan pada Musim tanam kedua, rata-rata biaya yang dikeluarkan pada musim tanam pertam sebesar Rp 75.047.412 per hektar sedangkan 
rata-rata biaya yang dikeluarkan pada Musim tanam kedua sebesar Rp 64.273.351 per hektar.

2. Terdapat perbedaan yang signifikan antara rata-rata harga tomat pada Musim tanam pertama dan Musim tanam kedua, rata-rata harga jual tomat pada Musim tanam pertama lebih tinggi dibandingkan harga jual pada Musim tanam kedua, pada Musim tanam pertama rata-rata harga jual tomat sebesar $\mathrm{Rp} 11.790 / \mathrm{kg}$ sedangkan pada Musim tanam kedua rata-rata harga jual tomat sebesar Rp 5.435/kg.

3. Terdapat perbedaan yang signifika antara rata-rata pendapatan usahatani tomat pada Musim tanam pertama dan Musim tanam keduaa, pendapatan pada Musim tanam pertama lebih besar dibandingkan pada Musim tanam kedua, dimana rata-rata jumlah pendapatan pada Musim tanam pertama sebesar Rp 150.430.781 per hektar sedangkan pada Musim tanam kedua sebesar Rp 20.304.842 per hektar. Yang

4. Masalah yang dihadapi petani tomat pada musim tanam pertama di Kecamatan Alas Kabupaten Sumbawa yaitu serangan hama dan penayakit, curah hujan rendah, harga tomat yang fluktuatif. Sedangkan pada musim tanam kedua masalah yang dihadapi oleh petani resonden adalah hama dan penyakit, cuaca atau iklim hujan yang deras, harga yang flutuatif dan harga pasara yang cukup rendah

\section{Saran}

Berdasarkan hasil penelitian dan dari hambatan yang timbul dalam penelitian ini makan hal-hal yang dapat dijadikan saran yakni :

1. Untuk memperoleh hasil yang efektif maka petani memerlukan penanganan hama dan penyakit secara cepat dan tepat.

2. Untuk menstabilkan harga tomat perlunya adanya peran pemerintah untuk menyediakan pasar atau mitra sehingga petani bisa menjual hasil yang telah di panen.

3. Untuk mengatasi kendala yang dikeluhkan oleh petani, penting adanya daya dukung dan kerjasama dari pihak pemerintah sebagai penentu kebijakan.

\section{DAFTAR PUSTAKA}

Arif, Abubakar. (2008). Akutansi Keuangan Dasar 2. PT. Grasindo: Jakarta.

BPS NTB. (2016). Nusa Tenggara Barat Dalam Angka 2016. Badan Pusat Statistik Nusa Tenggara Barat: Mataram.

BPS NTB. (2017). Nusa Tenggara Barat Dalam Angka 2016. Badan Pusat Statistik Nusa Tenggara Barat: Mataram..

Nursan, M., Ayu, C., \& Suparyana, P. K. (2020). Analisis Keuntungan dan Kelayakan Ekonomi Usahatani Tembakau Virginia di Kabupaten Lombok Tengah. Jurnal Ilmiah Membangun Desa Dan Pertanian, 5(3), 105-111.

Nursan, M., \& Septiadi, D. (2020). Penentuan Prioritas Komoditas Unggulan Peternakan di Kabupaten Sumbawa Barat. Jurnal Agribisnis Dan Ilmu Sosial Ekonomi Pertanian, 5(1), 29-34.

Simanjuntak, P. (1998). Pengantar Ekonomi Sumber Daya Manusia. Jakarta : Lembaga Penerbit Fakultas Ekonomi Universitas Indonesia.

Sugiyono. (2014). Metode Penelitian Kuantitatif Kualitatif dan R\&D. Bandung: Alfabeta.

Surantiyah. (2008). Ilmu Usahatani. Penebar Swadaya: Jakarta.

Suratiyah, K. (2015). Ilmu Usahatani. Penebar Swadaya: Jakarta.

Sudjana. (1992). Metode Statistika. Tarsito: Bandung. 